\title{
Incentive Package, Employee's Productivity and Performance of Real Estate Firms in Nigeria
}

\author{
Olayinka C. Oloke \\ Abiodun S. Oni
}

Department of Estate Management, College of Science and Technology, Covenant University, Canaanland, Ota, Ogun State, Nigeria

\section{Daniel O. Babalola}

Department of Architecture, College of Science and Technology, Covenant University, Canaanland, Ota, Ogun State, Nigeria

\section{Raphael A. Ojelabi}

Department of Building Technology, College of Science and Technology, Covenant University, Canaanland, Ota, Ogun State, Nigeria

\section{doi: 10.19044/esj.2017.v13n11p246 URL:http://dx.doi.org/10.19044/esj.2017.v13n11p246}

\begin{abstract}
The level of motivation received by an employee as reflected in the satisfaction with the base pay package and other incentives goes a long way to influencing the employees' attitude to work, loyalty, performance and job satisfaction. Employee's motivation and organization performance has been investigated across different fields and economic sectors. This study takes it further by examining incentive package, employees and organization productivity in real estate firms in Nigeria. Panel survey approach was adopted and three questionnaires administered in each of the one hundred and seventeen (117) estate firms in Ikeja, Victoria Island and Lekki Area of Lagos State. Respondents were two employees and one other in employers'/management capacity. Descriptive tools such as frequency and percentage were used to identify and determine the proportion of firms that make use of incentive package/option while a 5-point Likert scale and ranking were used to determine and rank the options in order of importance among these firms. Panel data regression model was used to determine the strength of relationship between firms' performance/productivity and incentives whilst holding other factors constant. Findings showed amongst others that there is strong positive correlation between incentive and employee productivity, employees are largely dissatisfied with the incentives offered by majority of estate firms and that incentive package is not the most important determinants of performance in real estate firms. The study
\end{abstract}


therefore concludes that employers in real estate firms pay attention to other factors identified and review remuneration and incentive package to boost the morale of their employees for better performance.

Keywords: Real estate firm, incentive, employee, performance, panel data

\section{Introduction}

Crucial to the success of an organization is competence of the management and workforce, employees' productivity on the other hand, had been hinged on the employee's capability and motivation received amongst other factors, to perform the various tasks assigned to the employee. Motivation, according to Lai (2009) may not necessarily drive chronic nonperformer to optimal productivity, however, a motivated workforce is a lubricant to the engine of the organization and its benefits include, dedication, employee retention, loyalty and harmony. These factors according to the author are crucial to the growth of the organization. Principal among the tools that can be used to motivate employee is incentive. Incentives according to Banjoko (2006) are defined as awards given out when predetermined objectives have been attained within an organization. It can also be regarded as variable payments made to employees on the basis of the amount of output or results achieved. Azasu (2003) however averred that incentives by definition may not be guaranteed but mostly contingent on performance. The use of performance incentives according to the author dates back to early $20^{\text {th }}$ century and conventional wisdom on the subject showed that there is a positive association between compensation and company performance.

Jeffrey and Shaffer (2007) reported that in 2004, 1 billion USD was spent on incentives and that number was expected to grow at $7 \%$ per annum. In India, of the 131 organizations where incentives were introduced, all the companies had a boost in production and productivity except those severely hit by economic recession (Jeffrey and Shaffer, 2007). The study revealed an average increase of $60 \%$ and $41 \%$ in the levels of output and productivity respectively thereby underscoring the importance and effectiveness of incentives in motivating employees. Incentives as motivational factors have been used in the private and public sectors and in the various line of business. Ude and Coker (2012) cite Tanzania where a public service incentive scheme tagged "Selected Salary Enhancement Scheme" SACE was instituted to motivate the civil servants. The scheme achieved its aim by adequately motivating the employees and also resulted in maximum impact on productivity. Furthermore, the author identified the impact of nonmaterial incentives on the Rwanda Revenue Authority with the introduction of incentives like agency autonomy, corporate values and reputation, 
effective human resource management and found that through this, the Agency was able to increase the impact of Rwanda Revenue Agency in the nation's GDP from 9\% - 13\%.

Delvecchio and Wagner (2007) observed the effect of different incentives on salespeople and concluded that younger salespeople react more dramatically and positively with higher intrinsic motivation when paid on plans with higher incentive proportion. Ojokuku (2011) also identified the effect of financial incentives on information and communication technology professionals. Profit sharing plans, premium pay and cash bonus are the types of financial benefits enjoyed by these professionals which enhanced their motivation to work. In the real estate sector, Azasu (2004) identified the various incentives and benefits used in Sweden to include variable pay, asset loan, paid paternity and maternity leave, lunch allowance and travel insurance. The author also noted that training is not popularly used but the firms are willing to give allowance for self-initiated training. Identifying the types of incentives used by employers in estate firms and whether this significantly influences employee's productivity and firm's performance is the focus of this research. Indications from students and graduates estate management as well as those currently employed in real estate firms is that the pay package is not robust enough and that incentives are almost nonexistent. However, this was not empirically supported and this forms the basis of carrying out this study. Falola, Ibidunni and Olokundun (2014) incisively opined that the success of any organization is dependent on its ability to remunerate and reward workers.

\subsection{The Concept of Incentive}

National Productivity Council (n.d. retrieved, 2014) defined incentive as a measure stimulating human effort, whereby employees are driven to put in their best. Matocchio (2006) in Tongo (2006) encapsulated the concept of incentives defining it as compensation, other than basic wages and salaries that fluctuates according to employees' attainment of some standard, such as pre-determined benchmark, individual or group goals or organizational earning. Generally, incentives are variable payments made to employees on the basis of the amount of output or results attained (Banjoko, 2006). According to Tongo (2006), the use of performance incentives dates back to the era of scientific management movement, championed by Frederick Taylor in the $20^{\text {th }}$ century, and ever since then, the private sector has employed the use of incentives as a method to raise the productivity of their employees. Incentive provision is meant to drive employee to go extra mile to achieve better result. It is a tool that can be engaged by any employer of labour, whether public or private employer and regardless of the type of task involved. However, amongst the various forms of incentive, an employer is 
at liberty to engage anyone considered suitable and affordable. Being a vocation and profit driven, real estate management practitioners engage incentive provision to motivate workers and increase performance.

\subsection{Types of Incentives}

Different classifications of incentives have been recognized in literature. The National Productivity Council classified incentives into non-financial, financial and semi-financial. Non-financial incentive schemes are those for which no form of monetary benefit, direct or indirect is attached to it, for example, recognition, praise for achievement or hanging a picture on the wall of best employee of the month, a plaque for excellent service and the like. However this is sufficient enough only to supplement the financial incentives as non-financial incentives are not motivation enough as standalone incentives (NPC, n.d, retrieved 2015). Semi-financial incentives are those schemes that have some indirect monetary benefit but not directly linked with wages. Examples include promotions, company car and the likes. Financial incentives are the most popular form of incentives and have the benefit of option value; meaning that employees can do whatever they wish with it, which gives it an edge over other forms of incentives (Jeffrey and Schaffer, 2007). Moreover, Milgrom and Roberts (1992) state that incentives could be awarded to individuals as well as groups. Under the individual incentive plan, each employee is rewarded based on his individual performance. Individual incentive has been found to be substantially more effective than the group incentives (NPC, n.d, retrieved 2015). Group incentives compensate a number of workers that are part of a team for their combined effort in achieving the desired outcome. Group incentives are a way of instilling a shared sense of collective responsibility with the end game of achieving superior and above average performance in an organization (Azasu, 2003).

Short term incentives include annual bonuses and commission based on performance in the period immediately preceding its award while long term incentive refers to incentives that are not realized until some time period has elapsed (Azasu, 2003). Examples include, contribution to pension funds, non-vested options in which case the employee has to remain with the company for a set period of time in order to realize the options and if the employee leaves the company before the time period elapsed he loses the right to the options (Lazear, 1999). Overall, there is very little doubt that incentives have a positive impact on the productivity levels in an organization. Schraeder and Becton (1998) examine the impact of three incentive programs on employee productivity and found a positive correlation between incentives and employee productivity. The authors concluded that firms in the service industries that offer aggressive incentive 
structures create a hunger in the organization whereas those that provide comfortable base salaries foster complacency. Table I is a summary of options from which incentives can be combined into packages.

Table 1: Options of Incentives for Employee Motivation

\begin{tabular}{|l|}
\hline Pay, Salaries, “efficiency wages” \\
\hline $\begin{array}{l}\text { Direct financial benefits e.g. Pension, illness/health/life insurance; allowances (clothing, } \\
\text { housing), subsidies, profit sharing, car loan }\end{array}$ \\
\hline $\begin{array}{l}\text { Indirect financial benefits such as subsidized meal, clothing, accommodation, transport, } \\
\text { scholarship, tax breaks, seniority pay }\end{array}$ \\
\hline $\begin{array}{l}\text { Flexible Schedules e.g. Part-time, temporary work, sabbatical, study leave, holidays, casual leave, } \\
\text { paternity and maternity leave, annual leave, vacation }\end{array}$ \\
\hline Work environment condition, Occupational health, safety, recreational facilities, \\
\hline Amenities, access to school, infrastructure, transport \\
\hline Job security, career, professional development, training opportunities \\
\hline Feedback coaching, value by organization \\
\hline Solidarity, socializing, camaraderie, affection, passion \\
\hline Status, prestige, recognition \\
\hline Sense of duty, purpose, mission \\
\hline Security, opportunities, stability, risk \\
\hline
\end{tabular}

Source: United Nations Development Programme Conference Paper (2006)

\subsection{Employee and Organization Productivity}

Productivity is usually defined as the ratio of inputs to outputs. It essentially measure how efficiently production inputs such as labour and capital are being used to produce a given level of output (Krugman, 1994). Okoye and Ezejiofor (2013) opined that organizational productivity is the measure of how well an organization functions and also an indication of efficiency and competition. Also it is a measure of how well resources are brought together and utilized for accomplishing set objectives (Mali, 2008 in Okoye \& Ezejiofor, 2013). Productivity is a global concern, which has inseparable ties to the longevity of the organization (Druckman, Singer \& Van Cott 1997 in Arraya, 2013). It is the key for survival in the cut-throat world of business and gives the organization a key competitive advantage above its peers when it is able to do more with less (Weaver, 2008 in Arraya, 2013). The baseline for economic productivity of an organization is the strength and quality of human capital. Human capital refers to the skills, abilities, competencies and qualities of an organization's employees. It comprises of the knowledge and expertise employees apply to produce products and services and to the operations of the organization, its equipment and machineries (Weaver, 2008 in Arraya, 2013). When human capital is adequately motivated, it leads to enhancement in productivity and service delivery.

\subsection{Factors Influencing Firm's Performance}

Different studies have been carried out on various factors affecting performance across various fields such as economics, strategic management, 
accounting and finance (Barney, 2001; Levinthal, 1995) and findings revealed generally that profitability measures tend to converge towards long run average values that are specific to each firm (Lev, 1983; Lipe and Kormendi, 1994). Different factors affecting employee and organization performance across different sector and industry in an economy have also been identified. For instance risk management and corporate governance, (Nosa and Ose, 2010); capital structure, size, growth, tax and risk (Onaolapo and Kajola, 2010; Krishna and Moyer, 1997). Akben-Selcuk (2016) identifies nine factors influencing firm's competitiveness. These are leverage, ratio of fixed assets to total assets, liquidity, investment ratio, size, age of the firm, location, export performance and management competence. Safarova (2010) also identified eight factors that affect firms' performance, namely intangibles, corporate governance, cash on hand, leverage, firm specific risk, size, growth and tangibility. Thus depending on the nature of goods produced or service rendered as well as the economy, the performance of different firms may be affected by similar or different factors and to varying extent. Generally, incentive package can be financial, non-financial, tangible or intangible. In order to identify those that directly affect real estate practice, the incentive package identified in Table 1 is empirically tested among employees of the profession.

\subsection{Theoretical Framework}

The expectancy theory of motivation opines that the effort put into an endeavor is positively related to the value of the reward offered (Jeffrey and Shaffer, 2007). Generally expectancy theory posits that what motivates an individual to select a particular behaviour out of a myriad of options is as a result of the expectation of a desirable outcome from the decision to follow that behaviour. Simply put, the theory suggests that the level of motivation that results in job satisfaction and better productivity is dependent on the availability of required resources input and adequacy of incentive provided. This consequently sets a rational pattern of human behaviour for the employees which systematically culminate into achieving the desired result that will earn him the additional package. This forms the basis of undertaking this research particularly among real estate practitioners, to unravel the type of incentive package and its adequacy to bring about job satisfaction and enhanced productivity among employees.

In addition, agency theory according to Perrow (1986) re-establishes the importance of incentives and self-interest in organizational thinking. The theory focuses on determining the most efficient contract governing the principal-agent relationship. Specifically, the theory attempts to find out if behaviour-oriented contract (salaries, hierarchical governance) is more efficient than outcome-oriented contract (e.g. commission, stock options, 
transfer of property rights, market governance). Specifically, agency theory is directed at the ubiquitous agency relationship in which one party (the principal) delegates work to another (the agent), who performs the work. Eisenhardt (1989). The principal-agent theory is concerned with the principal-agent relationship as applicable to employer-employee, lawyerclient, buyer-supplier and other agency relationships (Harris and Raviv, 1978). This relationship is examined in this context of real estate profession and the extent to which incentive is provided and motivated employees to affect the performance of employees and firm's productivity altogether.

\subsection{Research Methods}

The Directory of the Nigeria Institutions of Estate Surveyors and Valuers, (2016), contain 343 Estate Surveying and Valuation Firms registered and operating at different parts of Lagos State. For the purpose of this study, three clusters comprising the 79 in Ikeja, 34 in Victoria Island and 4 Firms in Lekki were selected. Panel survey was used to assess the stability of the hypothetical construct and to identify the determinants of the stability. With the panel survey, the strength of relationship between the independent variables and the dependent variable over a period of time was determined. Three questionnaires were administered per firm, two to employees and one to anyone in employer/management capacity. The questionnaires were used to elicit information on the types or patterns of incentives used by estate firms, other factors influencing employees' productivity as well as the nexus between productivity and incentives among these firms. Descriptive tools such as percentage was used to identify and determine the proportion of firms that use each incentive option while 5-point Likert scale and ranking were used to determine and rank in order of importance among these firms. Panel data regression model was used to determine the relationship between firms' performance/productivity which is the dependent variable and incentive package which constitutes the independent variables whilst holding other factors constant. The multiple regression analysis assesses the degree and character of relationships between a dependent variable and independent variables. Estimated regression coefficients indicate the relative importance of each independent variable in the prediction of the dependent variable. Findings were presented in tables and charts and discussed.

\subsection{Data Analysis and Discussion}

\subsection{Response Rate Analysis}

Table 2: Questionnaire Administration and Retrieval

\begin{tabular}{lccc}
\hline Respondent Group & No. Distributed & No. Retrieved & Response Rate \\
\hline Employers/Managers & 117 & 86 & $73.50 \%$ \\
Employees & 234 & 159 & $67.95 \%$ \\
Total & 351 & 245 & $69.80 \%$ \\
\hline
\end{tabular}


A total of 351 questionnaires were administered to respondents from 117 registered firms in Ikeja, Victoria Island and Lekki in Lagos State. The rate of response recorded for each group of respondents was above average and the overall average rate of response of $69.80 \%$ indicates the percentage of questionnaires appropriately completed by the respondents and fit for subsequent analysis.

\subsection{Incentives used by Real Estate Firms}

Respondents were requested to indicate the options of incentive used to motivate employees using the options of incentive in Table 1 . This is a multiple response question where respondents were allowed to indicate more than one incentive package offered by the firm. Response from employers in the real estate firms was used for the analysis in this section and the choices expressed in percentage. The summary was presented in Table 3.

Table 3: Incentive options used in estate firms

\begin{tabular}{cccc}
\hline Incentive option & Respondents & $\begin{array}{c}\text { Percentage of } \\
\text { Respondents }\end{array}$ & Rank \\
\hline Base Pay/Salary & 86 & $100 \%$ & $1^{\text {st }}$ \\
Pension & 86 & $100 \%$ & $1^{\text {st }}$ \\
Insurance & 53 & $61.6 \%$ & $3^{\text {rd }}$ \\
Commission & 25 & $29.1 \%$ & $8^{\text {th }}$ \\
Seniority pay & 43 & $50 \%$ & $6^{\text {th }}$ \\
Staff bus & 9 & $10.5 \%$ & $9^{\text {th }}$ \\
Official car & 64 & $74.4 \%$ & $2^{\text {nd }}$ \\
Leave (Casual, Maternity,Annual) & 86 & $100 \%$ & $1^{\text {st }}$ \\
Training/Workshop/Seminar & 52 & $60.5 \%$ & $4^{\text {th }}$ \\
Professional development & 24 & $27.9 \%$ & $8^{\text {th }}$ \\
Recognition & 45 & $52.3 \%$ & $5^{\text {th }}$ \\
Feedback & 38 & $44.2 \%$ & $7^{\text {th }}$ \\
\hline
\end{tabular}

Table 3 revealed the different incentive options and the proportion of firms that use them. The percentages were ranked to provide a quick glance at how the options fare in usage. The analysis showed that base pay/salary, pension and leave rank first in use. Apart from the fact that most firms are used to monthly remuneration packages for their employee, pension was a matter of employment policy directive by the government while casual leave, maternity leave or annual leave is granted as deemed necessary or warranted. The use of official car ranked second, though for management staff such as head of department, branch manager of regional manager. This was also to promote the firms brand. Insurance ranked $3^{\text {rd }}$ and upon further enquiry, most of the firms only provide insurance cover for employee when applying for public or multinational job opportunities that necessitates insurance cover for staff involved. This could be the reason why only $61.6 \%$ indicated the use of this option. Training, recognition, seniority pay ranks $4^{\text {th }}, 5^{\text {th }}$ and $6^{\text {th }}$ in 
use while feedback and professional development rank $7^{\text {th }}$ and $8^{\text {th }}$ in use. Most firm encourage their employees to undertake professional development but do not sponsor or finance the process for them. However, most attested to frequent use of in-house organized training to develop staff for optimal productivity.

\subsection{Factors Influencing Performance in Real Estate Firm}

Apart from incentives and pay package, other factors have been found to affect employees' productivity and firms' performance. The factors are listed and respondents are requested to rank it according to their level of influence on the overall performance.

The various factors that influence the performance of servicerendering firms such as real estate firms are listed for the purpose of finding their importance from the perspective of both the employer and employee. Mean weighted scores of each factor is calculated and then ranked accordingly. From the analysis, it was revealed that management competence ranked $1^{\text {st }}$, followed by competent manpower, logistics and resources, periodic training, incentives, and economic condition which ranked $2^{\text {nd }}, 3^{\text {rd }}$, $4^{\text {th }}$ and $5^{\text {th }}$ respectively from the perspective of the employers. Invariably, incentive package is considered one of the very important factors affecting firm performance but not the most important. Other factors considered important by employers are base salary, size of firm, operating cost, marketing and capital availability which ranked $6^{\text {th }}, 7^{\text {th }}, 8^{\text {th }}, 9^{\text {th }}$ and $10^{\text {th }}$ respectively in order of importance.

Table 4: Factors influencing Performance of Real Estate Firms

\begin{tabular}{|c|c|c|c|c|}
\hline \multirow{2}{*}{$\begin{array}{l}\text { Factors influencing performance of real } \\
\text { estate firms }\end{array}$} & \multicolumn{2}{|c|}{ Employer } & \multicolumn{2}{|c|}{ Employee } \\
\hline & Mean (M) & $\begin{array}{l}\text { Ranking( } \\
\text { R) }\end{array}$ & Mean (M) & $\begin{array}{l}\text { Ranking } \\
\text { (R) }\end{array}$ \\
\hline Location of firm & 2.6335 & 11 & 2.7312 & 9 \\
\hline Size of firm & 3.1084 & 7 & 3.2813 & 6 \\
\hline Age of firm & 2.4636 & 13 & 2.6511 & 12 \\
\hline Management competence & 3.7209 & 1 & 3.5723 & 2 \\
\hline Periodic Training/Workshop & 3.2674 & 4 & 3.5786 & 1 \\
\hline Research and development & 2.7558 & 10 & 2.7799 & 7 \\
\hline Economic condition & 3.2442 & 5 & 3.2956 & 5 \\
\hline System risk & 2.5020 & 12 & 2.6604 & 11 \\
\hline Specific risk & 2.3421 & 14 & 2.5188 & 14 \\
\hline Availability of capital & 2.7558 & 10 & 2.6918 & 10 \\
\hline Operating cost & 3.0581 & 8 & 2.7359 & 8 \\
\hline Logistics and resources & 3.3837 & 3 & 3.3019 & 4 \\
\hline Competent manpower & 3.4186 & 2 & 3.5723 & 2 \\
\hline Incentives & 3.2674 & 4 & 3.5409 & 3 \\
\hline Base salary & 3.1395 & 6 & 3.2956 & 5 \\
\hline Marketing & 2.8953 & 9 & 2.6604 & 11 \\
\hline Government Policy & 2.5020 & 12 & 2.6164 & 13 \\
\hline
\end{tabular}


Furthermore, from the perspective of the employees, periodic training ranked $1^{\text {st }}$, followed by competent manpower and management competence ranked which ranked $2^{\text {nd }}$, incentives which ranked $3^{\text {rd }}$, logistics and resources ranked $4^{\text {th }}$, economic condition and base salary ranked $5^{\text {th }}$. By implication, incentive package constitutes one of the very important factors influencing firm's performance. The analysis showed at a glance that though, base salary and incentives are considered critical to motivating employees to perform, other factors that rank $1^{\text {st }}$ to $6^{\text {th }}$ from both perspectives are equally very critical drivers of performance. The level of importance attached to others as depicted by their ranking on the relative importance index table and by implication, all the factors listed are acknowledged by the respondents to affect performance.

\subsection{Relationship between Organization Performance and Incentive Package}

Having determined the significance of incentive package among other factors to organization and employee performance, effort was made to find the degree of relationship between both variables. Performance being the dependent variable and incentive package being the independent variable, a panel data regression analysis was carried out. The relationship between the variables is depicted as follow: $\mathrm{Y}=\alpha+\beta \mathrm{X}$

Y represent organization performance is the dependent variable $\alpha$ represents the intercept

$\beta$ represent the beta value, slope or coefficient

$\mathrm{X}$ represent incentive which is the independent variable

Based on the options of incentives offered by the estate firms as indicated in Table 3:

$\mathrm{X}=f\left(\mathrm{x}_{1}, \mathrm{x}_{2}, \mathrm{x}_{3}, \mathrm{x}_{4}, \mathrm{x}_{5}, \mathrm{x}_{6}, \mathrm{x}_{7}, \mathrm{x}_{8}, \mathrm{x}_{9}, \mathrm{x}_{10}, \mathrm{x}_{11}, \mathrm{x}_{12}\right)$

ceteris paribus,

$\mathrm{Y}=\alpha+\beta_{1} \mathrm{x}_{1}+\beta_{2} \mathrm{X}_{2}+\beta_{3} \mathrm{x}_{3}+\beta_{4} \mathrm{x}_{4}+\beta_{5} \mathrm{x}_{5}+\beta_{6} \mathrm{x}_{6}+\beta_{7} \mathrm{X}_{7}+\beta_{8} \mathrm{X}_{8}+\beta_{9} \mathrm{X}_{9}+\beta_{10} \mathrm{x}_{10}+$ $\beta_{11} \mathrm{x}_{11}+\beta_{12} \mathrm{x}_{12}$

Where $\mathrm{x}_{1}$---- $\mathrm{x}_{12}$ represent the incentive options which are base pay, pension, insurance, commission, seniority pay, staff bus, official car, leave, training, professional development, recognition and feedback. The result of the panel data regression analysis as extracted from the SPSS analysis is presented in Table 5. Model summary after running the multiple regression analysis with the dependent and independent variables is reported in Table 5. The Table shows that the independent variables used in the model explain $41.7 \%$ of variance observed in the dependent variable. 
Table 5: Model Summary

Model Summary

\begin{tabular}{|r|r|r|r|}
\hline Multiple R & R Square & \multicolumn{1}{|c|}{$\begin{array}{c}\text { Adjusted R } \\
\text { Square }\end{array}$} & $\begin{array}{c}\text { Apparent Prediction } \\
\text { Error }\end{array}$ \\
\hline .715 & .473 & .417 & .182 \\
\hline
\end{tabular}

Dependent Variable: Firm Performance

Predictors: base pay, pension, insurance, commission, seniority pay, staff bus, official car, leave, training professional development, recognition and feedback

Thus at 95\% confidence intervals, the result showed that much of the variance in the dependent variable is explained by the regression model with Multiple $\mathrm{R}=.715$, Adjusted $\mathrm{R}^{2}=.417$ and the $\mathrm{R}^{2}=.473$. This implies that the regression model explains about $41.7 \%$ of the variance in the performance of real estate firms. The result also showed $(\mathrm{F}=3.915, \mathrm{p}=$ .003); suggesting that the results and regression model are statistically significant at $\mathrm{p}<.005$.

Table 6: Co-efficients of Independent Variables

\begin{tabular}{|c|r|r|r|r|r|}
\hline \multicolumn{5}{|c|}{ Coefficients } \\
\cline { 2 - 3 } & \multicolumn{2}{|c|}{ Standardized Coefficients } & Df & F & Sig. \\
\cline { 2 - 3 } & \multicolumn{1}{|c|}{ Beta } & $\begin{array}{c}\text { Bootstrap } \\
\text { (1000) Estimate } \\
\text { of Std. Error }\end{array}$ & & & \\
\hline Base Pay/Salary & .205 & .124 & 3 & 2.465 & .003 \\
Pension & .156 & .105 & 1 & 2.193 & .001 \\
Insurance & .201 & .188 & 2 & 3.431 & .000 \\
Commission & .282 & .273 & 1 & 1.261 & .001 \\
Seniority pay & .228 & .201 & 2 & 1.126 & .001 \\
Staff bus & .213 & .234 & 1 & 2.593 & .002 \\
Official car & .243 & .124 & 3 & 3.815 & .003 \\
Leave & .233 & .231 & 2 & 1.732 & .002 \\
Training & .251 & .189 & 2 & .306 & .000 \\
Professional development & .263 & .194 & 2 & 3.185 & .000 \\
Recognition & .209 & .173 & 1 & 1.031 & .002 \\
Feedback & .133 & .131 & 1 & 0.352 & .003 \\
\hline
\end{tabular}

Dependent Variable: Performance of Estate Firm

Table 6 showed the result of the panel data regression analysis of dependent variable against each of the independent variables in the model. The Table showed that all the twelve independent variables (incentive options) used in the regression model significantly predicts the financial performance of real estate firms. Thus from the result, at the significant pvalue $<.005$, all the independent variables has their p-value less than .005 ranging from .000 to .003 . By implication, the twelve variables are statistically significant to predicting the value of the dependent variable which is the firm financial performance. Literally, the availability of these 
incentives in an organization significantly motivates employees to be dedicated, loyal and perform optimally on their tasks. The beta $(\beta)$ value which represent the slope or co-efficient of each of the independent variables showed the strength of contribution or prediction of each incentive option to the financial performance of the firm in the long run assuming other determinants as identified in Table four are held constant.

\subsection{Adequacy of Incentive Package in Real Estate Firms}

In concluding, the adequacy of incentive and the level of satisfaction with the package by employees of real estate firms were assessed on a 5point likert scale. Mean score was calculated and interpreted using the scale by Morenikeji, (2006). Result of the analysis was presented in Table 7.

- $\quad 1-1.5=$ Strongly Disagree

- $\quad 1.51-2.5=$ Disagree

- $\quad 2.51-3.5=$ Undecided

- $\quad 3.51-4.5=$ Agree

- 4.51 - 5.0 - Strongly Agree

Table 7: Adequacy of Incentive Package in Real Estate Firm

\begin{tabular}{lcc}
\hline Incentive Package & Mean Score & Comment \\
\hline Base pay & 3.3503 & Undecided \\
Pension & 2.1422 & Disagree \\
Insurance & 1.4459 & Strongly disagree \\
Commission & 2.3106 & Disagree \\
Seniority pay & 2.5110 & Undecided \\
Staff bus & 1.3606 & Strongly disagree \\
Official car & 2.6823 & Undecided \\
Leave (annual, maternity, casual) & 2.4531 & Disagree \\
Training & 2.3323 & Disagree \\
Professional development & 3.4352 & Disagree \\
Recognition & 3.0102 & Disagree \\
Feedback & 1.4142 & Strongly Disagree \\
\hline
\end{tabular}

The trend of analysis as derived from the response of employees to the enquiry about the adequacy and satisfaction of the employees with incentive packages offered by employers of real estate firms is shown in Table 7. The results of the Likert scale analysis showed that majority of the incentive package provided are neither adequate nor satisfactory as analysis showed that respondents (employees) disagree generally or undecided with the adequacy and satisfaction with incentives package offered by these firms.

\subsection{Conclusion and Recommendations}

This study has examined the relationship between incentive and firm's performance with emphasis on employees' motivation across real estate firms in Nigeria. All the variables were tested and just like it had been 
established earlier that there is a strong positive relationship between incentive and organization performance. All the variables in the research were tested and it was found out that strong relationship exists among the variables having subjected the collected data to empirical analysis with the panel data multiple regression analysis. The result of the regression analysis further establishes the independent variables that are significant to predicting performance of real estate firms as well as the strength of their prediction as depicted by their respective beta value. However, the result indicated that not all the incentive options are offered or used in estate firms and that the choice of incentive packages differs significantly among the firms. The study further revealed other determinants of firm financial performance and shows that incentive package is among the first five important determinants of the performance of real estate firm. The study therefore concluded that there is need for estate firms to improve on incentives in order to maximize the potentials of their employees. Since, different packages and several options of incentive are available to the employer to use, management could conduct opinion poll among the staff to identify the options and package of incentive preferred so as to avoid wastage, discontentment and dissatisfaction. Meanwhile other determinants of organization performance should be looked into in order to have a balance of factors that will engender proper motivation to go extra-mile to deliver on the company tasks.

\section{References:}

1. Akben-Selcuk E., (2016). Factors affecting Firm Competitiveness: Evidence from an Emerging Market. International Journal of Financial Studies 4(9) 1-10 doi:10.3390/ijfs4020009

2. Arraya, M. \& Pellissier R. (2013) Productivity Measurement in a Sports Organization Southern African Business Review 17 (1) 98-127

3. Azasu, S. (2003) Incentive Plans Within Real Estate Firms - A Partial Review of Existing Literature. Working Paper No 51, Real Estate Economics. Retrieved from http://eres.scix.net/data/works/att/db82.content.00379.pdfAzasu

4. Azasu, S. (2004). Using Pay and Benefits in a Swedish Real Estate Firm. Retrieved from http://eres.scix.net/data/works/att/db82.content.00379.pdf

5. Banjoko, S. (2006) Managing Corporate Reward Systems, Lagos: Pumark Nigeria Limited

6. Commercial Real Estate Women (CREW) Network, 2008

7. Directory of the Nigeria Institutions of Estate Surveyors and Valuers, 2016 
8. Del Vecchoi, S. \& Wagner, J. (2007). Motivation and Monetary Incentives. Journal of Management and Marketing research. 7(1), 113

9. Druckman, D., Singer, J.E. \& Van Cott, H. (Eds). (1997). Enhancing Organizational Performance. Washington DC: National Academy Press.

10. Eisenhardt, K.M., (1989). Agency Theory: An Assessment and Review. Academy of Management Review, 14(1), 57-74.

11. Falola, H.O, Ibidunni A.S, \& Olokundun, M. (2014). Incentives Packages and Employees' Attitudes to Work: A Study of Selected Government Parastatals in Ogun State, Southwest Nigeria. International Journal of Research in Business and Social Science 3(1) $63-74$

12. Harris, M. \& Raviv, A. (1978). Some Results on Incentive Contracts with Application to Education and Employment, Health Insurance and Law Enforcement. American Economic Review, 68 (20-30).

13. Jeffrey, S. \& Shaffer, V. (2007). The Motivational Properties of Tangible Incentives. Sage Publications.

14. Krishnan \& Moyer (1997). "Performance, Capital Structure and Home Country: An analysis of Asian Countries”, Global Finance Journal, Issue 8(1), 129-143.

15. Krugman, P. (1994). Defining and Measuring Productivity. Retrieved from https://www.oecd.org/std/productivity-stats/40526851.pdf

16. Lai, C. (2009). Motivating Employees through Incentive Programs. Bachelor Thesis, Jvyasklya University of Applied Sciences

17. Lazear, E. (1999). Output-based Pay - Incentives or Sorting NBER Working Paper 7419

18. Matocchio, J. (2006) Strategic Compensation: A Human Resource Management Approach, New Jersey: Prentice Hall

19. Milgrom, P. \& Roberts, J. (1992). Economics, Organization and Management Englewood Cliffs, NJ: Prentice Hall

20. Morenikeji, W. (2006). Research and Analytical Methods: For Social Scientists, Planners and Environmentalists, Jos: Jos University Press.

21. National Productivity Council (India) (n.d, retrieved in 2015). Theory of Incentives. Retrieved from http://www.productivityinknowledgebase/general/incentives.pdf

22. Nosa \& Ose, (2010). Capital Structure and Corporate Performance in Nigeria: An Empirical Investigation, Journal of Management Sciences, 1(1):43-52

23. Ojokuku, R. \& Oyedokun, A. (2011). Efficacy of Financial Incentives - An assessment of Medium Scale firms Entrepreneurial Firms. International Journal of Economics 1(4)37-41 
24. Okoye, P. \& Ezejiofor, R. (2013). Effect of Human Resource Development on Organizational Productivity. International Journal of Academic Research in Business and Social Sciences 3(10) 250268.

25. Oliver R. (1974). Expectancy Theory Prediction of Salesmen's Performance Journal of Marketing research XI: 243-253

26. Onaolapo \& Kajola (2010). Capital Structure and Firm's Performance: Evidence from Nigeria, European Journal of Economics, Finance and Administration Sciences, Issue 25, 70-82

27. Perrow, C. (1986). Complex Organizations. New York: Random House

28. Safarova, Y. (2010). "Factors that Determine the Performance of New Zealand Listed Companies" An M.Sc. Dissertation submitted to Aukland University of Technology, School of Business in Partial Fulfilment of the requirements for the Degree of Masters of Business

29. Schraeder, M. \& Brecton, B. (1998). An Overview of Recent Trends in Incentive Pay Programs. The Coastal Business Journal 2(1) 18-27

30. Smoot, D. \& Duncan, P. (1997). The Search for the Optimum Individual Monetary Incentive Pay System: A Comparison of the Effects of Flat Pay and Linear and Non-linear Incentive Pay on Worker Productivity. Journal of Organizational Behaviour Management, 17(2): 5-75.

31. Tongo, C.I. (2006). Incentive Factors Affecting Productivity of Public Servants in Ogun State; Evidence from Ado-Ota Local government Arear Retrieved from: http://www.ilo.org/public/english/iira/documents/congress/regional/la gos2011/istparallel/sessionk/incentivesfactor.pdf

32. Ude, U. and Coker, M. (2012). Incentive Schemes, Employee Productivity and Motivation in Organizations in Nigeria Journal of Business Management 1(4) 32-39

33. Weaver, S.J. (2008). Characteristics for success: Predicting Intervention Effectiveness with the Job Characteristics Model. Unpublished MSc dissertation, University of Central Florida, Orlando

34. Wolf, E. \& Zwick T. (2008). Reassesing the Productivity Impact of Employee Involvement and Financial Incentives. Schmalenbach Business Review, Vol. 60, https://ssrn.com/abstract $=1280863$ 